\title{
Vietnamese Banking System in the Context of ASEAN Financial Integration
}

\author{
Hao Thi Kim $\mathrm{DO}^{1}$, Lan Khanh $\mathrm{Chu}^{1}$ \& Phuong Minh Nguyen ${ }^{1}$ \\ ${ }^{1}$ Banking Academy of Vietnam, Vietnam \\ Correspondence: Hao Thi Kim DO, Banking Academy of Vietnam, Vietnam.
}

Received: December 16, 2016

Accepted: January 8, 2017

Online Published: January 11, 2017

doi:10.5430/ijfr.v8n1p155

URL: http://dx.doi.org/10.5430/ijfr.v8n1p155

\begin{abstract}
This paper enlightens the main features of ASEAN Banking Integration Framework (ABIF) and the requirements for Qualified ASEAN Banks (QABs). Using Moody's evaluation method and Bankscope database for banking systems in 7 ASEAN countries, the paper compares Vietnamese banking system with the rest of the region on asset quality, capital adequacy, profitability and liquidity aspects. The results show that Vietnamese banks are relatively low-developing, and will face fierce competition from foreign banks on their home market. Measuring the effects of integration appears essential for the regulators and banks in seeking appropriate and prompt solutions to these challenges and in seizing valuable opportunities to obtain sustainable and efficient development.
\end{abstract}

Keywords: commercial banks, banking integration, ASEAN

\section{ASEAN Banking Integration Framework (ABIF)}

ASEAN Economic Community (AEC) was established on December 31 2015. It has become one of the three important pillars in ASEAN Community, along with Security pillars and Culture - Society pillars. AEC tends to advance the economic linkages among ASEAN states, including route to the economic integration. To facilitate trade liberalization and international capital mobility, the financial integration in general and banking integration in particular are essential for all ASEAN countries. However, besides the growth opportunity in a market of 600 million people and a GNP of $\$ 2,4$ trillion, the progress to economic integration appears competitive and challenging for banking system in ASEAN countries.

The degree of financial - banking integration among ASEAN countries is still relatively low compared with others. The financial systems in ASEAN countries are developing in favour of bank-based, rather than market-based system. As the gap in banking system development across group members still persists, the willingness to banking integration differs among countries. From the beginning, the ASEAN countries has identified that the banking integration is a critical mechanism to maintain the pace of financial services liberalization in ASEAN region. Being aware of the importance of banking system, in December 2014, the central banks in ASEAN endorsed the ASEAN Banking Integration Framework (ABIF) that further advances the integration of the region's banking system, which will be led by the Qualified ASEAN Banks (QABs). The QABs are ASEAN banks satisfying all stringent qualifications set by group members such as for the financial capability, risk management, capital adequacy requirements and prudential standards compliance.

Some notable points hereby about ABIF and QABs are important to help small banks to expand their operation to bigger foreign markets, thereby creating more favourable conditions for inter-ASEAN community's investment and trade.

First, although the ABIF was signed by all 10 members, the banking integration agreement under ABIF is between two countries and not to be signed by all 10 national members. This means that there are many agreements on banking integration within ASEAN and the more economically developed country will be able to integrate more quickly than less-developed countries. Therefore, the ABIF's 2020 goal is only semi-integrated financial market between several countries and not fully integrated financial market in the region.

Second, the principles of equality in term of market access and business environment are applied to all banks in ASEAN; helping banks of a ASEAN state member have better access to the regional market and be fully capable of operating flexibility as an indigenous banks in other countries members. 
Third, the principle of reciprocity in the bilateral agreements is followed to ensure that the degrees of financial integration among countries are more evenly.

Fourth, in order to be treated according to the ABIF principle, banks in ASEAN countries must meet certain standards of financial capacity and corporate governance quality, which referred to as QABs.

Firth, ABIF includes programs supporting the development of banking system, to ensure that all ASEAN members, especially in countries where banking system less developed, such as Vietnam, Lao, Cambodia, Myanmar, achieve the ABIF goal.

Sixth, to assist in monitoring effectively the operation of QABS, the supervisory coordination mechanism among ASEAN countries will be strengthened simultaneously with the implementation of ABIF.

\section{Assessment of Vietnamese Banking System in the Region}

As a member of ASEAN since 1995, Vietnam has shown its active role in promoting the regional development in general, and the economic integration in particular. In recent years, Vietnam has integrative actively into the regional and world economy through a number of bilateral and multilateral free trade agreements, and participation in AEC. The WTO accession process, the participation in FTAs and most recently the participation in AEC and TPP has opened many opportunities and challenges for Vietnamese banking system. Not only have to compete with banks from countries in region, Vietnamese banks also have an interest in expanding their operations to neighbouring countries. In order to overcome these challenges and utilize the opportunities, Vietnamese banking system needs to recognise its position in ASEAN banking systems first.

The authors use the Moody's evaluation method to conduct a comparison of the operation of Vietnamese banking system with other ASEAN countries. According to Moody's approach, banks are evaluated on the basis of asset quality, capital adequacy, profitability and liquidity. In each aspect, a key variable is selected to reflect the real state of the banks, and a few additional criteria are selected to provide further analysis of their situation. Moody also provides a scale (Note 1) that reflect the real situation of the banks in each aspect, where bank is classified as Very Weak (VW), Weak (W), Moderate (M), Strong (S), or Very Strong (VS).

To compare the operation of Vietnamese banking system with others in ASEAN region, Bankscope database spanning from 2010 to 2014 is used. The commercial banks, saving banks, cooperative banks and mortgage banks are chosen for the sample. The authors have excluded the investment banks, microfinance institutions, finance companies and trust funds, because of the differences in functioning. Banks with lack of financial data until 2014 are also excluded from the sample. The total sample size is 190 banks.

\subsection{Asset Quality}

Due to the high financial leverage, a small decline in asset value could cause significant impact on the solvency of the bank. Based on Moody's method, the authors select NPL ratio (Non-performing loans / total loans) as basic criteria to assess the asset quality of the banking system in ASEAN countries. In 2014, the NPL ratio of Vietnamese banking system was 2.02\%, ranked the fourth highest in region (higher than Singapore, Malaysia and Cambodia). Compared to the period from 2010 to 2014, the 2014 NPL ratio of Vietnam's banking system was mitigated by the sale of NPL to VAMC and the use of risk provisions. 


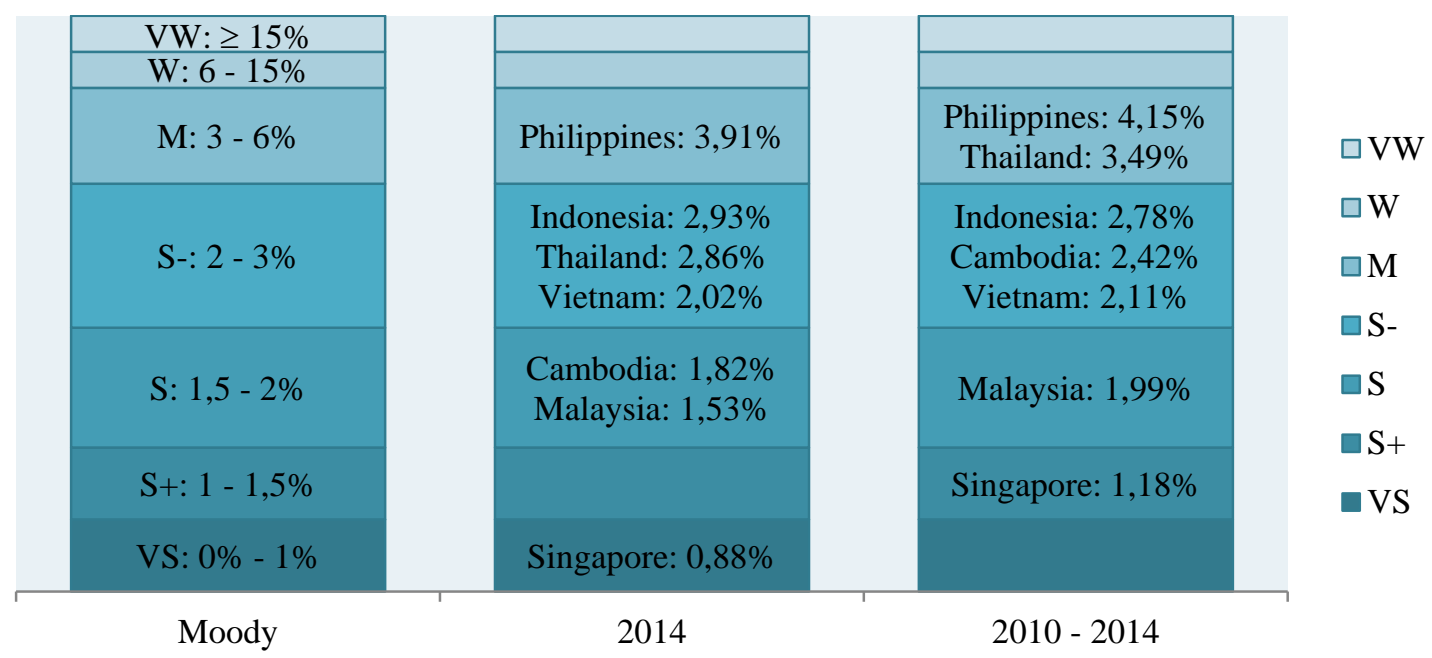

Figure 1. NPL ratios in ASEAN's banking systems and Moody's measuring scale

Sources: Bankscope, Moody, and authors' calculation

Although the NPL ratio has decreased and ranked middle among 7 ASEAN countries, the resilience again credit risk of Vietnam's banking system remains low. The first problem of credit risk is that highest part of NPL still remained in VAMC's balance sheet (at the end of 2015, credit institutions sold around 210 thousand of billions VND to VAMC and the recovery ratio was only around 20 thousand of billion VND) and there have not been any effective solution to deal with such loans. After 5 years, if commercial banks and VAMC cannot resolve such impaired loans, they will be returned to the commercial banks and it will be the their responsibility to resolve such loans.

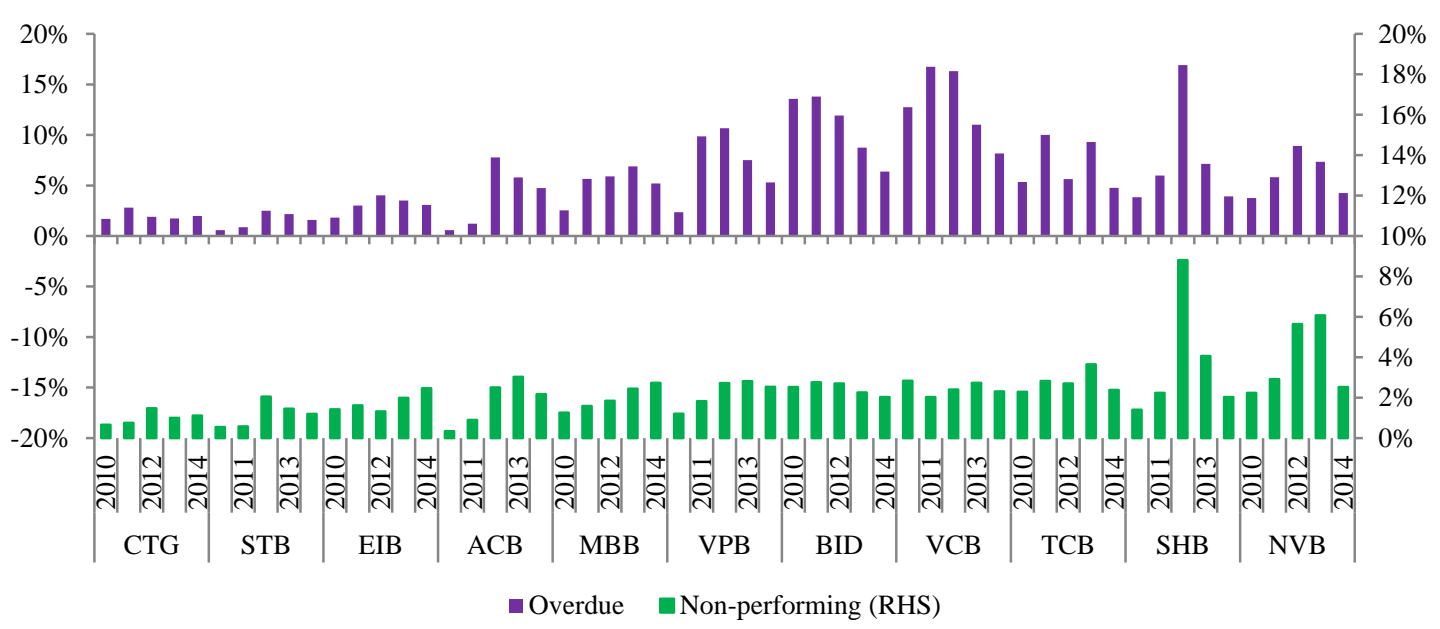

Figure 2. Overdue and non-performing loan ratio of some Vietnamese commercial banks

Source: commercial banks' annual reports

The second problem is the bank's provision for credit risk. This can be expressed by the loan loss provision coverage ratio, which was $73.33 \%$ in 2014 (just above Philippines). In the context of low credit quality and no external resources to handle the situation, the use of loan loss provision is still the main solution for Vietnam banks to reduce the NPL ratio. Compared to Cambodia, Thailand and Singapore which have loan loss provision higher than NPL size, Vietnam's loan loss provision coverage ratio is much lower. 


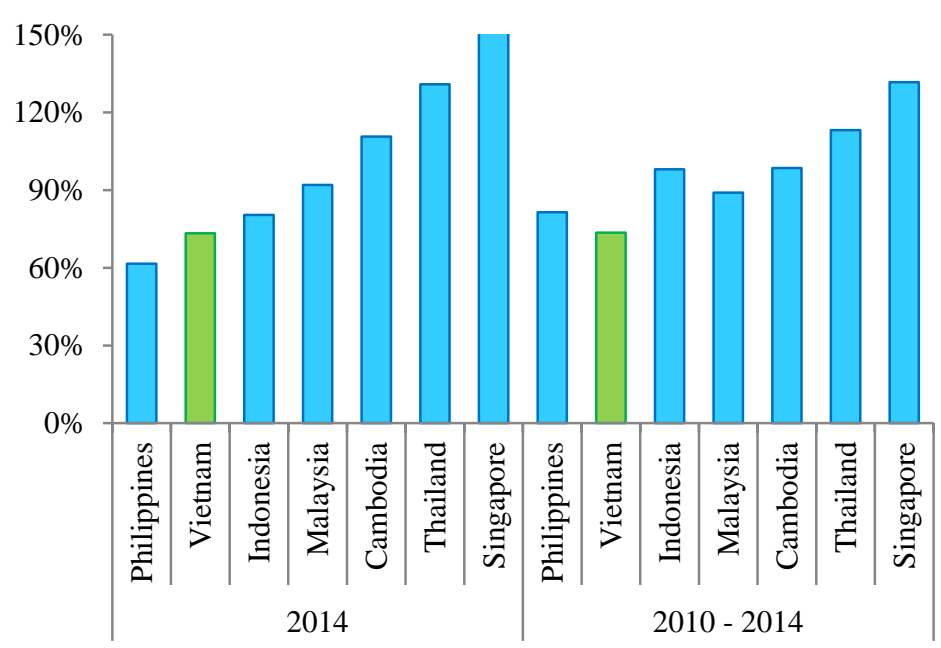

Figure 3. Loan-loss provision-to-NPL ratios of ASEAN's banking systems

Sources: Bankscope and Authors' calculation

\subsection{Capital Adequacy}

Equity is a measure of bank ability to absorb losses and allows banks to apply higher profitability strategies (at higher risk). The authors assess the capital adequacy of banking systems in ASEAN through the equity to total asset ratio. Of the seven countries in the region, Vietnam's equity-to-total asset ratio in 2014 is the lowest and clearly indicates the downward trend compared with the period from 2010 - 2014. It is due to the following reasons: (i) the unfavourable issue of share to increase capital, (ii) the limit on the sale of shares to foreign customers according to Vietnam regulation, (iii) the erosion of profit due to the loan-loss provision. However, the banking systems in Vietnam, Cambodia and Philippines possess the highest asset growth rate in the region. This feature has led to the concerns about the resilience against risks of Vietnam's banking system when the potential external risk increases along with the enhanced economic integration.

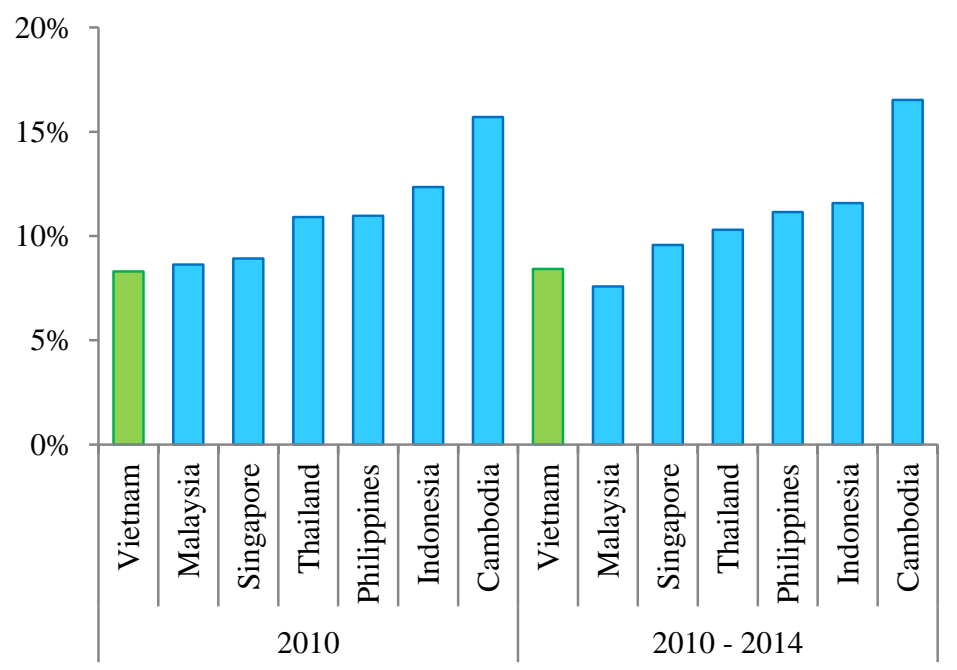

Figure 4. Capital to total asset ratio of ASEAN's banking systems

Sources: Bankscope and authors' calculation 
When calculating the capital adequacy ratio of commercial banks, there have been some limitations in risky assets classification as the banks classify assets from high-risk categories into low-risk ones. This argument is evidenced by the fact that the capital adequacy ratio is always significantly higher than capital to total asset ratio as well as the spread only decreases when macroeconomy and other risky areas remain stable.

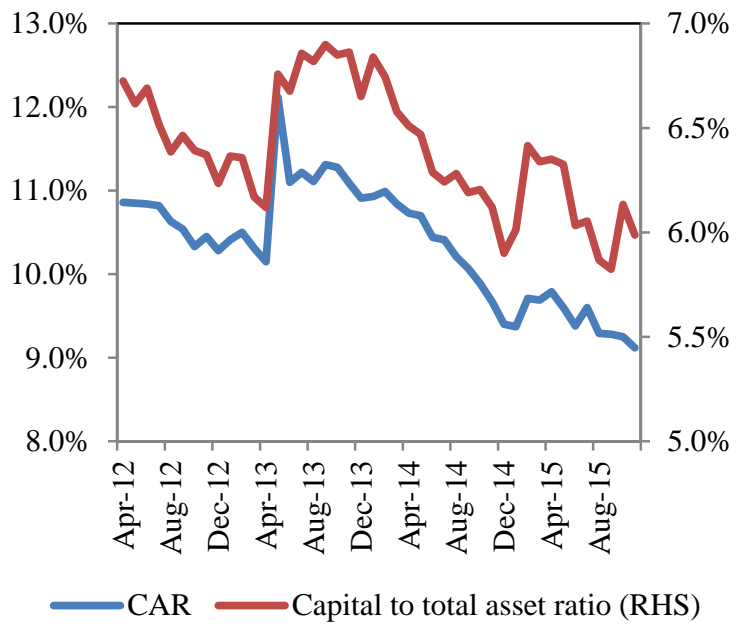

Figure 5. CAR ad capital to total assets ratio of state-owned commercial banks

Source: State bank of Vietnam

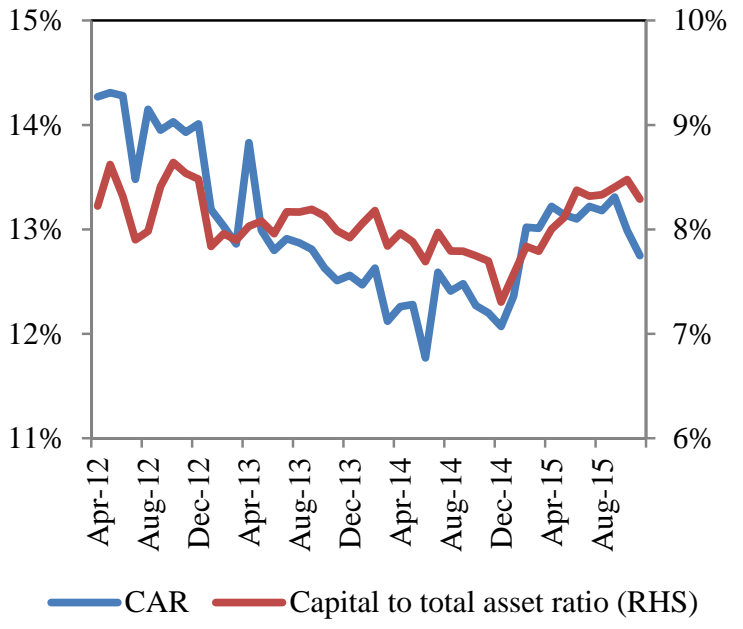

Figure 6. CAR ad capital to total assets ratio of private commercial banks

Source: State bank of Vietnam

\subsection{Profitability}

Profitability indicates how much profit a bank can earn commensurate with the level of risk, contributing to the increase in equity and partly to the absorption of losses. Based on Moody's analysis, the authors tend to assess the profitability of ASEAN's banking systems using return on tangible assets (total assets less goodwill and other intangible assets). Other indicators including the net interest margin [NIM, = (interest receivables - interest incurred)/total assets] and cost-to-income ratio are also taken into account for analysis.

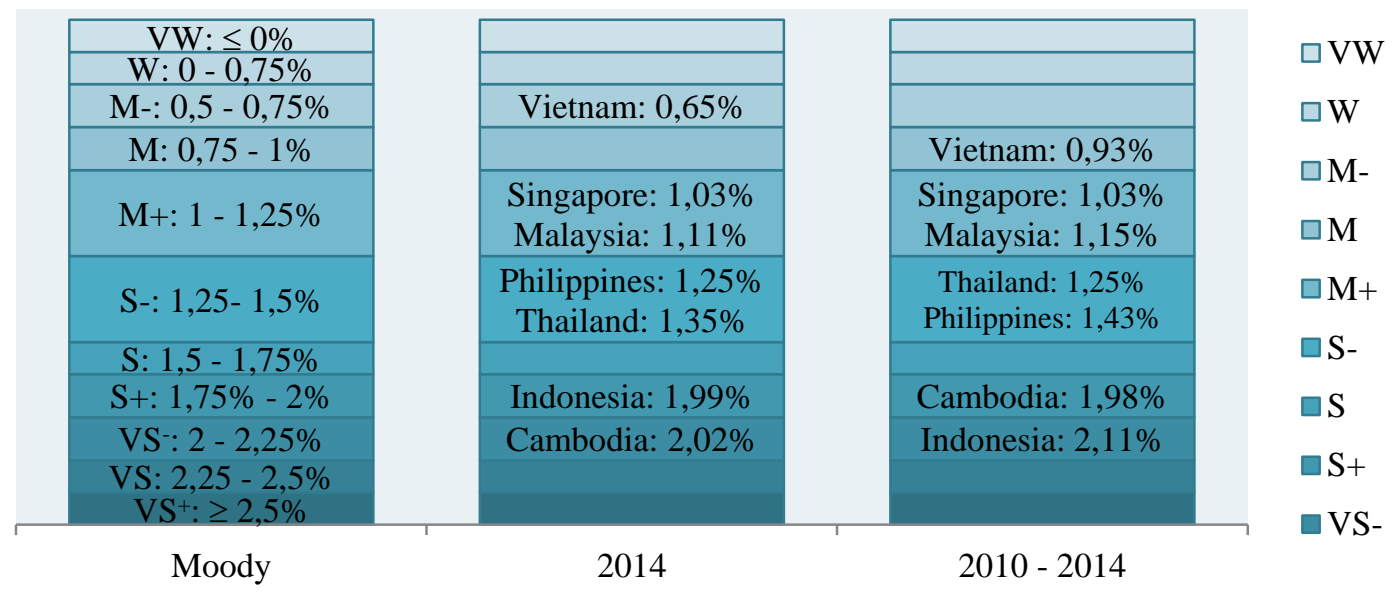

Figure 7. Return on tangible assets of ASEAN's banking systems and Moody's rating

Source: Bankscope, Moody and Authors' calculation 
Profitability of Vietnam's banking system is not only at the lowest level among the 7 ASEAN countries, but in sharp decline over the 2010-2014 period. Slower credit growth rate due to economic recession has caused the fall in profit from lending - a key operation of Vietnam's banking system. Although Vietnam surpasses Singapore and Malaysia in net interest margin (thanks to its higher deposit rate ceilings and proportion of short-term deposits), the high-rise cost-to-income ratio and loan loss provision have induced a lower profitability for Vietnam than any other ASEAN countries.

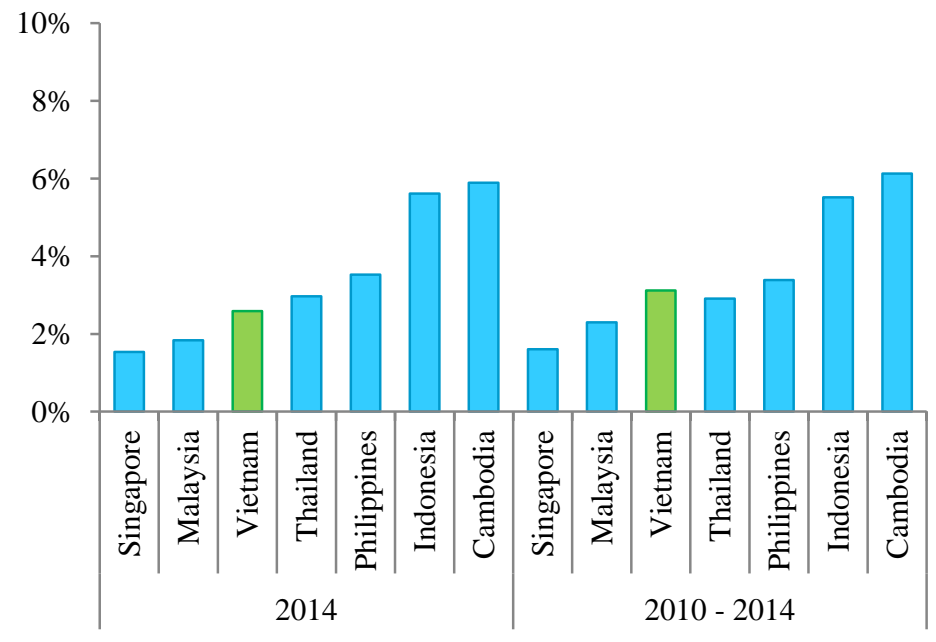

Figure 8. Return-on-assets (ROA) of ASEAN's banking systems

Source: Bankscope and Authors' calculation

Of the 7 ASEAN countries, Vietnam's banking system possesses the second highest cost-to-income ratio (following the Philippines), reflecting that competitiveness of Vietnamese banks is much weaker than rival countries in ASEAN region. In reality, cost management capability of ASEAN banks (particularly small-scale banks in the Philippines and fast-growing banks in Indonesia) are weaker compared with other countries around the globe.

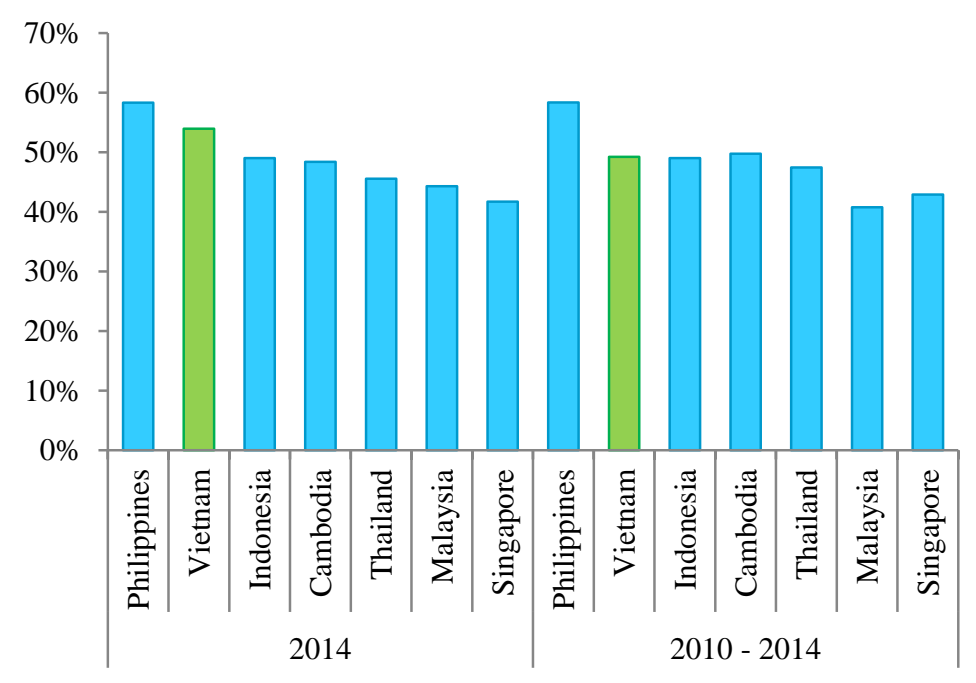

Figure 9. Cost-to-income ratio of ASEAN's banking systems

Source: Bankscope and Authors' calculation 
To ensure comparison of the profitability among ASEAN's banking systems in agreement with the level of risk, the paper uses "Z-score" - a measure of bank's insolvency.

$$
Z-\text { score }=\frac{R O A+\text { Equity } / \text { Assets }}{\sigma(R O A)}
$$

Z-score consists of three assessment components: profitability (return on assets), financial leverage (equity to total assets ratio) and earnings volatility (variance of return on assets). Obviously, this integrated indicator better reflects the state of excessive risk-taking than every single criterion. Of the 7 ASEAN countries, Vietnam's banking system has the highest level of risk (as measured by inverse of $Z$-score), yet lowest level of profitability (measured by ROA). Meanwhile, with low level of profitability obtained, the risk facing banking systems in Singapore and Malaysia seems under control.

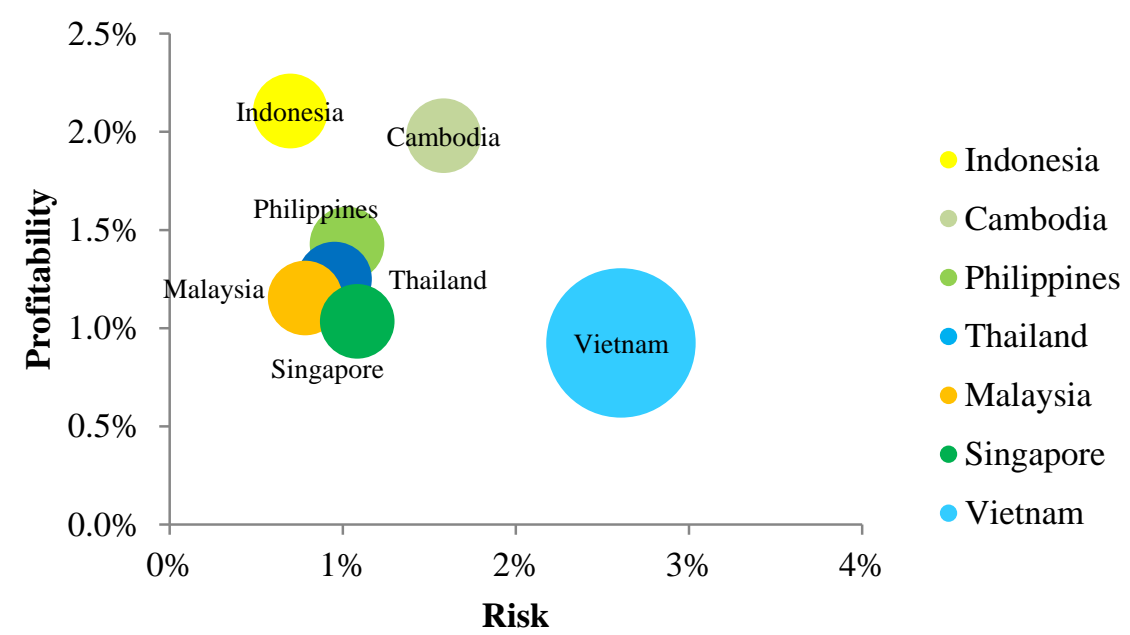

Figure 10. The relationship between profitability and risk of ASEAN's banking systems

Source: Bankscope and Authors' calculation

\subsection{Liquidity}

To assess the bank's liquidity situation, authors employ two indicators proposed by Moody's. The first indicator measures the share of short-term funding and prone to be withdrawn by highly sensitive-to-risk depositors. According to Moody's, organization's deposit and residents' are deemed far more stable than the wholesale funding from financial institutions (interbank market funds, short-term valuable papers, bonds, etc.) 


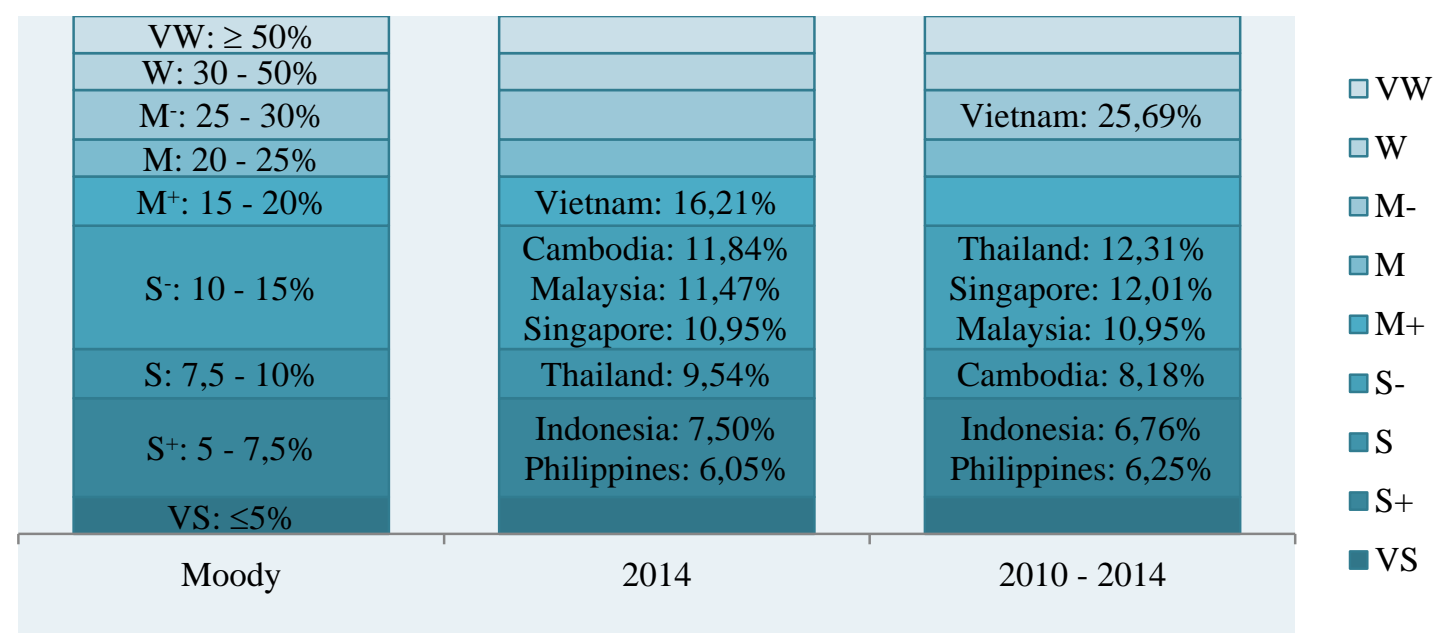

Figure 11. Share of short-term funding and prone to be withdrawn of ASEAN's banking systems and Moody's rating Source: Bankscope, Moody and Authors' calculation

Despite the dramatic downward trend, the share of easy-withdrawing-fund of Vietnam's banking system still ranks first among ASEAN countries. Among these funds, credit institution's deposit and short-term borrowings register the highest proportion although deposits from credit institutions has fallen sharply due to the more stringent regulations on interbank market management.

The second indicator measures the share of highly liquid assets in the bank's total assets. Banks can mobilize deposit more easily (even from the sensitive-to-risk depositors) if they maintain a large proportion of highly liquid assets to total assets.

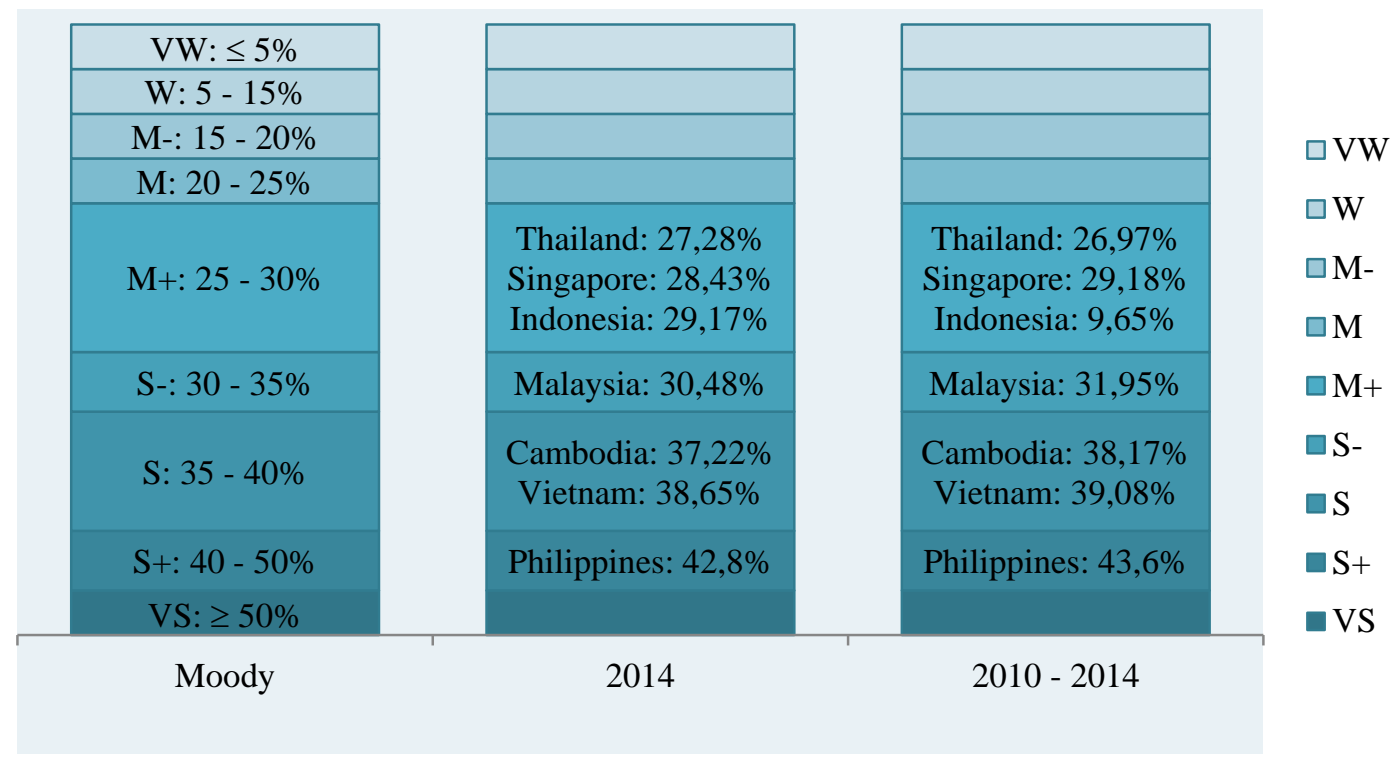

Figure 12. Liquid asset ratio of ASEAN's banking systems and Moody's rating Source: Bankscope, Moody and Authors' calculation 
Though ranked second in the 7 ASEAN countries, the majority of highly liquid assets of Vietnam's banking system are loans to other credit institutions, not the trading securities on the secondary market. Government bonds held by Vietnam's banking system are hardly ever traded on the secondary market, yet transact with the central bank.

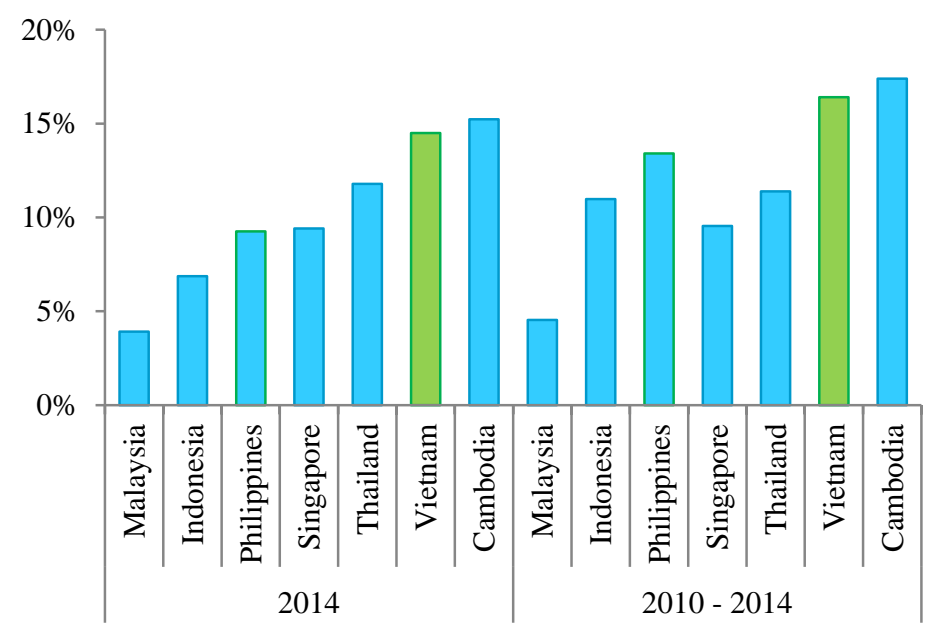

Figure 13. Share of deposits on the interbank market of ASEAN's banking systems

Source: Bankscope and Authors' calculation

Analytical results indicate that Vietnam's banking system is at a relatively low stage of development compared to the leading countries in the region like Singapore, Malaysia and Thailand. They are likely to be big competitor of Vietnam's banking system on the domestic market as the qualified ASEAN banks are permitted to expand operations in Vietnam and treated as domestic banks.

\section{Meassures for the Integration of Vietnamese Banking System}

To utilize opportunities brought by ABIF, Vietnamese banks, especially the "big 4" banks, need to meet the standards of a QAB, so that Vietnam could sign bilateral agreements with "top-ranked" countries in the region. However, the integration of Vietnamese banks into the ASEAN region still faces serious impediments and requires appropriate and proactive solutions.

First, analysis of the above-mentioned indicators as well as Vietnamese banks' ranking in the top 100 ASEAN banks (according to The Banker) shows Vietnamese banks are still classified as "underdeveloped" in the region. The top-class bank of Vietnam ranks merely 25th in The Banker's ranking table, far lower than that of the ASEAN-5 countries. To quickly catch up with more advanced economies in the region, Vietnamese banks need to take proactively M\&A deals, not only with domestic but also with foreign institutions, which, unquestionably, is the quickest way to expand and strengthen the financial resources of a financial institution.

Table 1. Number of banks and ranking of national top-class banks in the ASEAN Top 100

\begin{tabular}{cccc}
\hline & Country & $\begin{array}{c}\text { Number of banks in Top } \\
\mathbf{1 0 0}\end{array}$ & $\begin{array}{c}\text { ASEAN Top 100 ranking of } \\
\text { national top-class bank }\end{array}$ \\
\hline 1 & Singapore & 3 & 1 \\
\hline 2 & Malaysia & 23 & 4 \\
\hline 3 & Thailand & 18 & 5 \\
\hline 4 & Indonesia & 20 & 8 \\
\hline 6 & Philippines & 15 & 17 \\
\hline 7 & Vietnam & 19 & 25 \\
\hline 8 & Brunei & 1 & 55 \\
\hline
\end{tabular}

Source: thebankerdatabase.com 
Second, Vietnam is still beyond the bilateral integration process with other ASEAN countries within ABIF framework. The ASEAN-5 countries have actively signed bilateral agreements under ABIF to create a more favourable business environment for QABs in the region. Yet so far, Vietnam is expected to sign with Indonesia this year. Apart from bilateral agreements with Indonesia and other countries in the ASEAN's lower top, Vietnam should target top-ranked partners such as Thailand, the Philippines, Malaysia and Singapore, so as to create competitive dynamics for Vietnamese banks to fulfill higher standards.

Table 2. ABIF Bilateral Agreements among ASEAN countries

\begin{tabular}{ccc}
\hline & Bilateral Agreements between & Time of signing \\
\hline 1 & Malaysia - Indonesia & Dec 2014 \\
\hline 2 & Malaysia - Philippines & Mar 2016 \\
\hline 3 & Malaysia - Thailand & Mar 2016 \\
\hline 4 & Thailand - Philippines & Mar 2016 \\
\hline 5 & Thailand - Indonesia & Mar 2016 \\
\hline 6 & Indonesia - [Vietnam, Myanmar, Singapore, \\
& Cambodia] & 2017 (Expected) \\
\hline
\end{tabular}

Source: Authors' compilation

Third, the integration under ABIF framework would, in theory, make banks more vulnerable to outside risk. The fact that the drawbacks of Vietnamese banking system have not yet resolved are likely to pose risks to the bank's operation in the future. NPL ratio of the whole system drops below $3 \%$ by the end of 2015, but the handling of bad loans and restructuring of the banking system have achieved preliminary results. This may make the banks from other countries in the region more cautious when approaching Vietnam markets due to high risk aversion. Thus, the intrinsic weaknesses of Vietnam's banking system need to be resolved in order to enhance the financial strength of banks, reduce the systemic risk, and accelerate integration process in banking with other ASEAN countries.

To resolve the non-performing loans, VAMC and commercial banks should focus on two main issues. The first is the criteria for a loan to be bought by VAMC. VAMC should only buy the loans that it can manage more effectively than the commercial banks themselve. For example, large scale real estate is a good selection for the transfer from commercial banks to VAMC while small-size loans should be left to commercial banks. To achieve the economies of scale, all related non-perfornubg loans are grouped from many banks and its branches before selling to VAMC. It requires the strict adoption of Circular 02/2011/SBV to force banks to recognize and classify loans accurately and timely. The second issue is the price of the traded loans. For buying a nonperforming loan with market price, it seem very difficult to value impaired assets (especially in recession times). VAMC should rely on an approximate ratio of non-performing loan value to derive a price for transacting with commercial banks. Both parties can joint in an agreement that allows each side to receive a profit (or share a loss) after VAMC resolve the loans. This practice is necessary to foster the resolving speed, especially when the longer the time is, the quicker and higher value of the collaterals depcreciate.

To reduce the maturity mismatch, commercial banks should be encouraged to issue medium to long-term bonds and convertiable bonds. Variable-rate depositing- and saving products with built-in convenient and modern banking services will help banks to raise more stable deposits from customers.

Fourth, Vietnamese banks have yet operated under the international standards on risk management and corporate governance. The banks should increase the transparency and accountability of the bank with customers and of the board of directors and managers with shareholders. In return, it forces the BOD and BOM to act in the interest of shareholders, customers, increasing the trust from customers and partner to keep their market share from highly competitive foreign banks. In case of risk management, in Vietnam, Basel II compliance has only been piloted in the 10 banks but not in the entire system, while the ASEAN's top-ranked banking systems have already applied Basel II and Basel III. Corporate governance in the Vietnamese banking system seems rather poor as cross-ownership issue has not been thoroughly treated. Only when Vietnamese banks meet these standards, they could integrate into the ASEAN community under ABIF proactively, efficiently and effectively. Thus, Vietnam needs to quicken the application of Basel II in the banking system as well as encourage banks to utilize international best practices of 
corporate governance in order to fill the gap with top-ranked economies in the region.

Fifth, the foreign investor's ownership permitted by Vietnam's banking sector still remain low compared with other top-ranked countries in the region (20\% for Vietnam, 25\% for Thailand, 30\% for Malaysia, $40 \%$ for Indonesia, $100 \%$ for the Philippines and Singapore). Increase in foreign investor's ownership would create more opportunities for foreign investors to be involved in the Vietnamese market, as they could invest in a domestic bank with a certain level of control rather than having to establish a wholly foreign owned bank. This measure will help to increase the capital of Vietnamese commercial banks, establishing a firm basis for enlarging their business in domestic and foreign markets. Moreover, a higher capital adequacy ratio increase the bank's ability to respond to negative shock. Besides, along with "reciprocity" principle, the ASEAN countries will have to set generally consistent rules to ensure fair competition for the banks in the region. Therefore, the relaxation of regulations for foreign investors is the inevitable trend in the process of today's financial liberalization.

Sixth, the supervisory coordination between nations requires an harmonious regulations for banks across the ASEAN in order to avoid conflicts in the management of the national supervisory authorities. Institutions such as credit rating organizations, credit guarantee mechanism, interbank markets need to be established and stable before a country can actually dismantle entry barriers. Besides, infrastructure of the banking sector should also be upgraded in order to meet the requirements of integration and data security among nations.

\section{Conclusion}

In the context of ASEAN financial integration, Vietnamese banking system will definitely face aggressive competition from foreign competitors. This paper uses the Moody's evaluation method to compare the strength of Vietnamese banking system with the others in ASEAN region. The result indicates that although Vietnamese banks have undergone the restructuring process since 2011, they are still suffering problems in term of low asset quality, insufficient capital, low profitability and liquidity shortage. To overcome the weakness in order to integrate faster and catch up with the advanced economies in the region, Vietnamses banking system should focus on resloving the bad debts by fastening the VAMC bad debt restructering process, raising the medium- to long-term deposit and capital, improving the effectiveness of corporate governance, and step by step signing the bilateral agreements with the same level countries. Besides Indonesia as expected, Vietnam could set goals towards signed bilateral agreements with Thailand, the Philippines and Malaysia. Aside from being similar in terms of banking performance, the trade turnover between Vietnam and these countries remains rather enormous and has shown an upward trend during recent years. Undoubtedly, integration of the banking sector would play a big role in promoting trade between Vietnam and these countries in the coming years.

\section{References}

ASEAN Secretariat (2015). ASEAN Integration Report 2015. Jakarta: ASEAN Secretariat.

Moody's. (2016). Rating methodology. Retrieved from https://www.moodys.com/research/Banks--PBC_186998

SNL Financial. (2016). Asia-Pacific Financial Institutions: Regulatory Infographic.

The Insider Stories. (2016). OJK signs LoI with Bank of Thailand on ASEAN banking. Jakarta: The Insider Stories.

\section{Note}

Note 1. Moody's rating methodology: https://www.moodys.com/research/Banks--PBC_186998. 